\title{
Relationship between Abnormalities the Arcus Form Static and Dynamic Balance Levels In Class 1-4 Students for Primary School Muhammadiyah Ambokembang Academic 2018/2019 in Pekalongan District
}

\author{
Mega Widya Putri; Rifqi Sabita; Dzikra Nurseptiani \\ Bachelor Program of Physioteraphy Muhammadiyah Pekajangan University, Pekalongan, Indonesia
}

http://dx.doi.org/10.18415/ijmmu.v6i4.1031

\begin{abstract}
Training model to improve agility. The second stage is the product development stage with expert judgment with a percentage of $82 \%$. Furthermore, product testing, the results of small group trials with a percentage value of $80 \%$ and in large group trials with a percentage value of $85.78 \%$. Next in the third stage is the product effectiveness test by comparing experimental groups using an exercise model developed with a control group that uses conventional training. The design of the experimental design uses the Two Group pre test post test desgin design. Different values of T-scores for the agility test of the experimental group 85.22 and the control group 40.33. The development of a soccer training model proved to be significant in increasing agility at the special preparation stage. This study was conducted to determine the relationship between arch deformity with dynamic balance and static balance in students at SD Muhammadiyah Ambokembang. Arch deformity data was obtained from the pedis arch test, namely the wet footprint test, dynamic balance was obtained from the balance beam test and the static succession was obtained from a one foot stand test. This research was conducted on boys and girls at Muhammadiyah Ambokembang class 1-4 Primary School. In this study, there is a relationship between arch deformity with dynamic equilibrium $(\mathrm{p}<0.05)$ with value $(\mathrm{p}=0,000)$ and static balance with values $(\mathrm{p}=0,000)$. Many factors can affect a person's dynamic balance, namely physical, biomechanical, musculoskeletal, and somatosensory factors. However, from the results of this study it can be seen that musculoskeletal factors in the form of a pedis arch form in particular the arch form deformity turned out to greatly affect the dynamic balance in the elementary school students studied. Arche deformities can affect dynamic balance because the flat foot shape without curvature is less able to function as a rigid lever for leveraging the body when the foot will leave its footing in the walking process. This study provides the results that respondents experience impaired balance, especially when doing a static balance test that is by walking on long beams.
\end{abstract}

Keywords: Abnormalities; Arcus; Static; Dynamic 


\section{Introduction}

Foot arcs normally form from the first 5 years with an age range of 2-6 years (Karandagh, 2015). Ages 7-9 years belong to the late childhood which has enormous potential to optimize all aspects of development, including the development of motor skills. Age 7-12 years the child's motor ability reaches the stage of specialized skills, where the child has more control over his motor skills and achieves optimal motor development (Pudjiastuti, 2012). According to Permana (2013), states that motor skills are very influential on children's development. If there is a delay in motor skills, it will experience delays in the development and growth of children, which will affect functional abilities, especially mobility abilities such as decreased balance, increased risk of falls and decreased road speed (Indardi, 2015).

The ability to balance a child at the age of development is very important to be reviewed, both in terms of balance sitting, standing, and when walking. Balance is one of the most important parts or things in activities where everyone needs balance in maintaining their body position in moving or doing activities. A person's balance is also affected by age, where in children the location of the Center of Gravity is higher because the relative head is bigger than the feet, while as adults the location of the point of gravity will be closer to the fulcrum located in Sacrum II. This situation will affect the balance of the body, the lower the location of the center of gravity the pedestal will be closer to the fulcrum. (Saraswati et al., 2015).

Judging from a number of balance theories, it can be seen that balance is one of the important points for us to be able to walk, maintain the center of gravity and perform activities or movements with the risk of falling very minimal. Balance is the ability to maintain the body in the center of mass of the body (center of mass) against the plane of the fulcrum (base of support) to fight gravity (center of gravity) is influenced by sensory processes or the nervous system, motor or musculoskeletal, and external effects (Bacolinni, 2013).

\section{Methodology}

This study uses a correlational research method. Correlational research is research conducted to determine whether there is a relationship between the two variables or several variables. The method used is descriptive analytic cross sectional, cross sectional research is a study that studies the relationship between risk factors (independent) with effect factors (dependent), which makes observations or measurement of variables once and at the same time. The population in this study were Students Class 1 to 4 at Muhammadiyah Ambokembang Primary School in the 2018/2019 Academic Year in Kedungwuni District, Pekalongan Regency, with 250 students. The tool used to collect data in this study was a wet foot print test and a form test sheet using a Balance beam. The results of data collection will be processed by the following stages: editing, coding, processing, cleaning. 


\section{Result and Discussion}

This study was conducted to determine the relationship between arch deformity with dynamic balance and static balance in students at Muhammadiyah Ambokembang Primary School. The arch deformity data was obtained from the pedis arch test, namely the wet footprint test, dynamic balance was obtained from the balance beam test and the static succession was obtained from a one foot stand test. This research was conducted on boys and girls at Muhammadiyah Ambokembang Primary School in class I-IV.

Table 1: Relationship of Ark Deformity with Static and Dynamic Balance Level Disorder

\begin{tabular}{|c|c|c|c|c|c|}
\hline & & & Static_Balance & Dinamic_Balance & Grade_Flatfoot \\
\hline \multirow[t]{3}{*}{ SSpearman's rho } & Static_Balance & $\begin{array}{l}\text { Correlation } \\
\text { Coefficient } \\
\text { Sig. (2-tailed) } \\
\text { N }\end{array}$ & $\begin{array}{l}1.000 \\
40\end{array}$ & $\begin{array}{l}.866^{* *} \\
.000 \\
40\end{array}$ & $\begin{array}{l}-.945^{* *} \\
.000 \\
40\end{array}$ \\
\hline & Dinamic_Balance & $\begin{array}{l}\text { Correlation } \\
\text { Coefficient } \\
\text { Sig. (2-tailed) } \\
\text { N }\end{array}$ & $\begin{array}{l}.866^{* *} \\
.000 \\
40\end{array}$ & $\begin{array}{l}1.000 \\
40\end{array}$ & $\begin{array}{l}-.917^{* *} \\
.000 \\
40\end{array}$ \\
\hline & Grade_Flatfoot & $\begin{array}{l}\text { Correlation } \\
\text { Coefficient } \\
\text { Sig. (2-tailed) } \\
\text { N }\end{array}$ & $\begin{array}{l}-.945^{* *} \\
.000 \\
40\end{array}$ & $\begin{array}{l}-.917^{* *} \\
.000 \\
40\end{array}$ & $\begin{array}{l}1.000 \\
40\end{array}$ \\
\hline
\end{tabular}

**. Correlation is significant at the 0.01 level (2-tailed).

In this study, there is a relationship between arch deformity with dynamic equilibrium ( $p$ $<0.05)$ with value $(\mathrm{p}=0,000)$ and static balance with values $(\mathrm{p}=0,000)$. The same thing was also found in research conducted by Ali and Mohamed in 2011, which stated that there was a significant relationship between arch deformities with dynamic equilibrium $(\mathrm{p}=0,000)$. According to Benedettiet.al (2011) as many as $75.3 \%$ of children with arch deformities are unable to stand on one leg for a long time due to instability of the subtalar joint and the eversion of the subtalar joint which impedes balance during standing on one leg.

\section{Conclusion}

The age range of 7-9 years is the most common category that experiences arch deformities with disturbance of static and dynamic balance levels at Muhammdiyah Ambokembang Primary School, Pekalongan Regency with a percentage of $80 \%$. On average students out of a total of 40 respondents who experienced arch deformities and impaired dynamic and static balance were men with a total percentage of $52.5 \%$. The results showed there was a relationship between arch deformities with static and dynamic balance disorders where the correlation test results $\rho 0,000$ ( $>$ $0.05)$. 


\section{References}

Adhitya Pradana. 2014. Hubungan Antara Indeks Massa Tubuh (IMT) dengan Nilai Lemak Viseral. Jurnal Media Medika Muda. Fakultas Kedokteran, universitas Diponegoro.

Andriyani. 2016. Physical Activity Guidelines for Children. Jurnal Pendidikan Jasmani Indonesia, Volume 10, Nomor 1, April 2016 hal 61-67.

Delitto. 2003. "The Link Between Balance Confidence and Falling”.PhysicalTherapy Research That Benefits You, American Physical Therapy Association.

Giovanni., Greishberg. 2007. Foot and Ankle: Core Knowledge in Orthopeadics. Elsevier Mosby.

Harris. 2004. Diagnosis and Treatmen of Peditric Kelainan bentuk arkus. The Journal of Foot \& Ankle Surgery, Volume 43, No.6, November/Desember. American College of Foot and Ankle Surgeons.

Huxham. 2005. "Theoretical considerations inbalance Assesment". Australian Journal of Physiotherapy.

Lendra. 2009. Pengaruh antara Kondisi Kaki Datar dan Kaki dengan Arkus Normal terhadap Keseimbangan Statis pada Anak Berusia 8-12 Tahun di Kelurahan Karangasem Surakarta [Skripsi]. Surakarta : Jurusan Fisioterapi, Fakultas Ilmu Kesehatan Universitas Muhammadiyah Surakarta.

Santoso. 2011. Perawatan Tepat Bagi Anda yang Memiliki Telapak Kaki Datar (Kelainan bentuk arkus), Sport Injuries \& Rehabilitation, (Online),(http://duniafitnmemiliki-telapak-kaki-datarflat-feet.html., diakses 17 Juni 2019

Watson. 2008. "The Human Balance System” A Complex Coordination Of Central And Peripheral System By The Vestibular Disorders Association.

Wilson. 2008. Synopsis of Causation Pes Planus. Ninewells Hospital and Medical School, Dundee.

World Health Organization. 2007. WHO Global Report on Falls Prevention in Older Age. Perancis: WHO.

\section{Copyrights}

Copyright for this article is retained by the author(s), with first publication rights granted to the journal. This is an open-access article distributed under the terms and conditions of the Creative Commons Attribution license (http://creativecommons.org/licenses/by/4.0/). 